\title{
Do Mark 7:1-23 and Matthew 15:1-20 condone the unusual practices of New Prophetic Pentecostal Churches?
}

\begin{tabular}{|c|c|}
\hline \multicolumn{2}{|c|}{$\begin{array}{l}\text { Authors: } \\
\text { Vuyisile Qiki } \\
\text { Llewellyn Howes }\end{array}$} \\
\hline \multicolumn{2}{|c|}{$\begin{array}{l}\text { Affiliations: } \\
{ }^{1} \text { Department of Religion } \\
\text { Studies, Faculty of Humanities, } \\
\text { University of Johannesburg, } \\
\text { Johannesburg, South Africa }\end{array}$} \\
\hline \multicolumn{2}{|c|}{$\begin{array}{l}{ }^{2} \text { Department of Languages, } \\
\text { Cultural Studies and Applied } \\
\text { Linguistics, Faculty of } \\
\text { Humanities, University of } \\
\text { Johannesburg, Johannesburg, } \\
\text { South Africa }\end{array}$} \\
\hline \multicolumn{2}{|c|}{$\begin{array}{l}\text { Corresponding author: } \\
\text { Llewellyn Howes, } \\
\text { Ilewellynh@uj.ac.za }\end{array}$} \\
\hline \multicolumn{2}{|c|}{$\begin{array}{l}\text { Dates: } \\
\text { Received: } 01 \text { Apr. } 2021 \\
\text { Accepted: } 22 \text { June } 2021 \\
\text { Published: } 30 \text { July } 2021\end{array}$} \\
\hline \multicolumn{2}{|c|}{$\begin{array}{l}\text { How to cite this article: } \\
\text { Qiki, V. \& Howes, L., 2021, } \\
\text { Mark 7:1-23 and Matthew } \\
\text { 15:1-20 condone the unus } \\
\text { practices of New Prophetic } \\
\text { Pentecostal Churches?', } \\
\text { Verbum et Ecclesia 42(1), } \\
\text { a2254. https://doi.org/ } \\
\text { 10.4102/ve.v42i1.2254 }\end{array}$} \\
\hline \multicolumn{2}{|c|}{$\begin{array}{l}\text { Copyright: } \\
\text { (c) 2021. The Authors. } \\
\text { Licensee: AOSIS. This wo } \\
\text { is licensed under the } \\
\text { Creative Commons } \\
\text { Attribution License. }\end{array}$} \\
\hline \multicolumn{2}{|l|}{ Read online: } \\
\hline 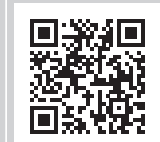 & $\begin{array}{l}\text { Scan this QR } \\
\text { code with your } \\
\text { smart phone or } \\
\text { mobile device } \\
\text { to read online. }\end{array}$ \\
\hline
\end{tabular}

The leaders of certain New Prophetic Pentecostal Churches (NPPCs) perform rituals that are very unusual when compared with traditional church rituals and practices. These practices include eating grass, rats or snakes, drinking petrol and spraying Doom on people so that they would be healed and be closer to God. The trend to perform these unusual rituals has spread throughout South Africa. Leaders from NPPCs often quote Mark 7:14-19 and Matthew 15:10-11, 16-18 to justify their actions. In this study, these parallel texts will be considered in their literary and socio-cultural contexts to determine whether or not they can be taken to condone the activities of these church leaders.

Intradisciplinary and/or interdisciplinary implications: The study will find that Mark 7:14-19 and Matthew 15:10-11, 16-18 either condone or do not condone the unusual activities of NPPCs and their leaders. Either way, the findings will be relevant for New Testament studies, practical theology, religion studies and systematic theology.

Keywords: Matthew; Mark; Pentecostal; church; unusual; practices; charismatic; bizarre; snake; petrol.

\section{Introduction}

In earlier publications, Kgatle (2017:1-2) uses the term 'Neo-Pentecostal Churches' and defines them as churches that are not bound by denomination. He also makes a clear distinction between Neo-Pentecostalism and classical Pentecostalism, stating that the latter believes in salvation through confession in the baptism of the Holy Spirit, which is followed by the gifts of the Holy Spirit, including particularly speaking in tongues. By contrast, Neo-Pentecostalism is known for refusing to either associate with other denominations or be part of the South African Council of Churches (SACCs) (Kgatle 2017:3). Neo-Pentecostal churches believe that their spiritual gifts will be suffocated by the rigid structures and authority of other churches. Nevertheless, they are characterised by a 'ministry of deliverance', because they minister directly to the needs of their congregants. Such needs often include sickness, joblessness, poverty, bewitchment, childlessness and so on. In more recent publications, Kgatle (2020a, 2020b, 2020c) uses the term 'New Prophetic Churches' (NPCs) for the same group of churches. Kgatle (2020a) describes 'NPCs' as follows:

The NPCs [New Prophetic Churches] are churches that have retained the fundamental teachings of Pentecostalism like the baptism in the Holy Spirit and speaking in tongues but have peculiar practices like one-on-one prophecy, one-on-one deliverance and consultations, where members pay a certain fee, miracle money, prophetic titles, with some prophets claiming superiority over biblical prophets and others. Prophecy is the most significant feature of these churches and has been the source of growth amongst the NPCs in South Africa. Even pastors who initially did not prophesy begin to engage in one-on-one prophetic ministry when they align to these types of churches. [...] In the context of pneumatological ecclesiology, most of the churches in the NPCs do not focus on the baptism of the Holy Spirit with the initial evidence of speaking in tongues. [...] New prophetic churches instead of talking about Spirit baptism, would rather speak about the demonstration of the power of the Holy Spirit amongst believers. (pp. 3-4)

In this study, the term New Prophetic Pentecostal Churches (NPPCs) will be used to express both the Pentecostal leanings and the centrality of prophecy in these new churches. The leaders of certain NPPCs perform rituals that are very unusual when compared with traditional church rituals and practices. These practices include making their congregants drink petrol (petroleum) or Dettol (a disinfectant or antiseptic liquid), ordering them to eat grass, live rats, ants or snakes, fondling people's private parts, ordering congregants to take off their clothes, spraying insecticides on people's faces and so on (see Jentile 2016:ix, 31, 64; Kgatle 2017:1, 3-5, 2020a:3-4, 5, 2020b:3; 
Khanyile 2016:22-27; Maluleke 2015:38-39; Mokhoathi \& Rembe 2017:1-2; Resane 2017a:1-17; Qiki 2020:35-51). These unusual practices have drawn much attention and criticism from different avenues, including especially the media and other religious communities (see Qiki 2020:51-63; cf. Kgatle 2017:5-8; Resane 2017b:1-8). To justify and legitimise their actions, NPPC leaders often quote Mark 7:15, where Jesus says that nothing entering the body can defile someone, or the parallel text in Matthew 15:11. For example, Prophet Penuel Mnguni of End Times Disciples Ministries in Soshanguve justified feeding his congregants frogs, mopane worms and dog meat by referencing this New Testament tradition (Qiki 2020:40). ${ }^{1}$ In this study, these parallel texts will be considered in their literary and socio-cultural contexts to determine whether or not they can be taken to condone the activities of these church leaders. The study is exegetical in that it analyses the chosen texts and makes exegetical and hermeneutical observations throughout. One may call the present approach 'topical exegesis', because the exegetical and hermeneutical observations revolve around a certain topic, as explained above. Given that this topic deals with contemporary concerns, one would further be justified in regarding this study as following a reader-response approach.

The pericope in Mark 7:1-23 can be divided into two sections: (1) verses 1-13 focus on Jesus' response to the Pharisees' objection that some of his disciples fail to wash their hands before eating food; (2) verses 14-23 focus on moral purity as a substitute for purity regulations regarding food (Garland 1996:271). Although they form part of the same pericope (e.g., Bock 2015:219-220; Boomershine 2011:130-131), we will treat these sections separately. Although the second section is typically used by NPPC leaders to justify their actions, especially the comment by Jesus that nothing entering the body can defile a person, the first section is not entirely irrelevant to the current discussion and forms part of the pericope. Finally, we will turn our attention to Matthew's version of this tradition in Matthew 15:1-20.

\section{Mark 7:1-13}

Mark 7:1-13 contains many authorial explanations of Jewish customs, including the following: (1) 'that is, unwashed' in verse 2; (2) verses 3-4; and (3) 'that is, devoted to God' in verse 11 (Donahue \& Harrington 2002:220). Another such authorial comment also appears in the next passage, at the end of verse 19: 'In saying this, Jesus declared all foods clean' (Bock 2015:224). According to Donahue and Harrington (2002:227), Mark 7:1-23 'is more dense with explanatory comments than any other section of Mark'. These explanatory comments support the conclusion by many scholars that Mark was written for a non-Jewish audience (Bock 2015:221; cf. Boomershine 2011:129; Boring 2006:199; Wessel 1984:678). Part of the function of the explanatory comment in verses 3-4 is to characterise the Pharisees as pedantic observers of all

1.For media reports, see https://www.sowetanlive.co.za/news/south-africa/2019-05 22-polokwane-pastor-boasts-of-feeding-congregants-dog-meat/ and https://www. news24.com/news24/southafrica/news/snake-pastor-feeds-dog-meat-tocongregants-for-communion-20181016. kinds of customs not actually proscribed in Scripture, thereby setting up Jesus' rebuttal in the rest of the passage (cf. Nolland 2005:610). This is supported by France (2002:281), who argues that the phrase 'and all the Jews' in verse 3 to indicate that all Jews were following the practices listed in verses 3-4 during the time of Jesus 'is more impressionistic than historically exact, since there is no evidence that the sort of precautions described were yet observed by Jews in general, if indeed they ever were' (cf. Bock 2015:221; Boring 2006:199). France (2002:281-282) continues: 'It was precisely the observance of such rules which marked out the members of the Pharisaic party from the general populace'. ${ }^{2}$

Commentators agree that washing one's hands before eating was not an Old Testament law during the time of Jesus, but rather a traditional Jewish and/or Pharisaic practice (e.g., Davies \& Allison 2004:520, 522). This is confirmed throughout the passage (cf. Gould 1969:125). In verses 3 and 5 , this practice is referred to as a 'tradition of the elders' instead of a law. Gould (1969:126) defines the Greek word

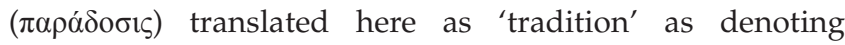
something that 'is passed along from one to another' and 'preserved by oral transmission from one generation to another'. Harrington (1991:229, 231) defines the term 'tradition of the elders' as 'the body of laws and customs that supplement or arise out of the Torah', and that 'made concrete more general teachings in the Torah or covered matters not treated in the Torah'. In verses 3-4, Jesus compares the handwashing ritual to other traditional practices that are likewise not Old Testament laws (Nolland 2005:610). In verse 7, Jesus applies the following quotation from Isaiah 29:13 (LXX) to this practice: 'their teachings are merely human rules' (Bock 2015:222; Boring 2006:200; Davies 1993:112; Schnackenburg 2002:148). In verse 8, which continues the quotation from Isaiah, Jesus accuses the Pharisees of keeping 'human traditions' ( $\tau \grave{v} v \pi \alpha \rho \alpha ́ \delta o \sigma v v \tau \tilde{\omega} v$

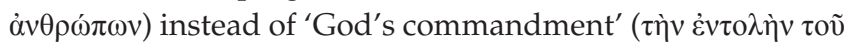
$\theta \varepsilon \circ \tilde{v})$ as part of his response to the indictment that his disciples fail to wash their hands before they eat (see Gould 1969:128-129). France (2002) paraphrases the implied argument of verse 8 as follows:

What comes from God has the authoritative character of $\dot{\varepsilon} v \tau o \lambda \eta$ [commandment], which requires obedience; what comes from human authority is merely $\pi \alpha \rho \alpha$ ó may not be of value in itself, but cannot have the same mandatory character. (p. 285)

Jesus repeats the same basic accusation in verses 9 and 13,

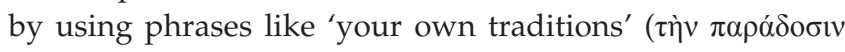
$\dot{v} \mu \tilde{\omega} v)$ and 'your tradition that you have handed down'

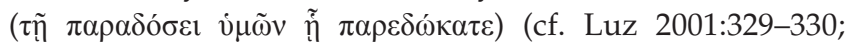
Nolland 2005:616). Bratcher and Nida (1961:230) define the latter phrase as 'customs which have been handed on to you and which in turn you hand on to others'. The handwashing practice was not a matter of hygiene (at least not primarily), but of ritual purity (see Nolland 2005:611-615). The concept 2.Davies and Allison (2004:521-522) argue that ritual handwashing before meals might have been more prevalent before $70 \mathrm{CE}$ than scholars suspect. 
of ritual purity will receive attention in the next section on verses $14-23$.

In short, Jesus accuses the Pharisees of making nonscriptural practices more important than regulations that actually appear in Jewish Scripture, sometimes even to the extent that they replace recorded laws with these traditional practices (Boring 2006:200; Davies \& Allison 2004:517; cf. Bock 2015:222). The verb used in verse 13 to describe what the Pharisees do to Old Testament law is 'nullify' (ג் which is a legal term that means to cancel, annul or repeal a certain regulation (Donahue \& Harrington 2002:223; France 2002:287-288). Gould (1969:130) regards the verb to mean 'invalidate'. Bratcher and Nida (1961:229) not only mention three denotative meanings, namely 'make void', 'annul' and 'invalidate', but also offer the following translation possibilities: 'refuse to consider important', 'make powerless', 'break' and 'take away its power'. Liddell and Scott (1996:59) provide the following translation possibilities: 'cancel', 'set aside', 'set as naught', 'treat as of no effect', 'reject', 'deny the validity of' and 'render powerless'. The verb $\dot{\alpha} \theta \varepsilon \tau \dot{\varepsilon} \omega$ in verse 9 also functions to describe what the Pharisees do to God's commandments and carries meaning possibilities like 'reject' and 'set aside' (Bratcher \& Nida 1961:227).

In verses 10-12, Jesus gives a specific example of how the Pharisees annul or invalidate Old Testament law by means of their manmade traditions. In this example, the law of honouring one's father and mother is nullified by a specific Pharisaic tradition. More broadly, Jesus argues that instead of judging his disciples for not washing their hands before they eat, the Pharisees should look at themselves and the way in which they harm and nullify Jewish law by insisting that everyone follows their manmade customs (cf. Bock 2015:222, 225; Duling 2010:304-305 Nolland 2005:610; see Boring 2006:200-201). According to Josephus (Ant. 13.297), the Sadducees rejected the Pharisees and their teachings for exactly the same reason, that is, because they taught traditions that were not part of Old Testament law to the Jewish people. The Pharisees treated their own traditions and practices as authoritative (France 2002:283; Nolland 2005:610). In this passage, Jesus questions 'the authority and validity of their traditions' (Garland 1996:272).

This text represents the immediate literary context of Mark 7:14-23, which is often used by NPPC leaders to support their unusual practices. There are two interesting points of contact between the activities of the Pharisees (as described in Mk 7:1-13) and the activities of the NPPC leaders mentioned in the introduction of this study. The first is that both the Pharisees and these particular NPPC leaders seem to use coercion and intimidation to get people to follow their customs. The second is that the customs of both the Markan Pharisees and these NPPC leaders are not instructed or commanded by the foundational texts of their respective authoritative traditions. In other words, just as the handwashing practice of the Pharisees is manmade in the sense that it does not appear in the Jewish Scriptures, the strange rituals of NPPC leaders are manmade in the sense that they do not appear in the Christian Scriptures. One important difference is of course that the handwashing ritual was not harmful to those who obliged, whereas the practices of NPPC leaders are often harmful. Although ancient Jews might not have known about the existence of viruses and bacteria, they might nonetheless have noticed the causal link between washing one's hands and not getting sick. Ancient Jews would therefore have regarded handwashing as either harmless or beneficial.

Although Jesus does not say so expressly in this text, he does seem critical of the Pharisees' tendency to impel others to follow certain customs. His whole diatribe in this passage is a response to the Pharisees' insistence that others also follow their manmade rituals (cf. Nolland 2005:610). One has to assume that Jesus would have responded in the same way to the tendency of NPPC leaders to coerce, manipulate and force people to partake in their manmade practices. Jesus calls the Pharisees hypocrites in verse 6, and continues to say in verse 9: 'You have a fine way of setting aside the commands of God in order to observe your own traditions!' (NIV). Can the same be said of some of these NPPC leaders? A positive answer to this question might not be premature at this stage. The actions of certain NPPC leaders do seem to contradict one of the two most important commandments of Jesus that summarise the Old Testament laws, namely to love one's neighbour as oneself (cf. Bock 2015:222). If these NPPC leaders are deliberately causing harm to their followers, they are not loving them in the way Jesus commanded. If this is correct, these NPPC leaders can indeed be accused of 'setting aside the commands of God in order to observe their own practices'.

Commenting on this text, Garland (1996:285) says: 'The Pharisees' lip service and religious gestures fool others and themselves into thinking that they are pious' (see also Bock 2015:222). To what extent is this also true of some modern Christians, including certain NPPC leaders? Some of the answers NPPC leaders give to critical questions would seem to support a positive answer to this question. Consider, if you will, the following exchange that formed part of an interview between eNCA $^{3}$ news anchor Shahan Ramkissoon and Prophet Lethebo Rabalago from Mount Zion General Assembly (MZGA), who sprayed Doom (a South African insecticide) in the faces of his congregants:

Ramkissoon: 'Now, what would you say to people who are saying that this is an unconventional method of healing people?'

Labalago: 'I don't know. They are not at my level. I just pray that God will help them to understand whatever that is happening now.' ${ }^{4}$

Such arrogance and self-importance seem comparable to the general attitude of the Pharisees as they are depicted in this text and the rest of the New Testament. In this regard, the 3.Electronic News Channel Africa.

4.The full interview is available at https://twitter.com/eNCA/status/8010327298 65265152 . 
term 'hypocrite' might also be applicable to certain NPPC leaders. Garland (1996:285) writes: 'The most infamous hypocrites are those who try to cloak the evil within them with a show of external piety'. If the NPPC leaders discussed earlier do misuse the Bible and feign piety to validate actions that harm others, the pejorative description 'hypocrite' would indeed apply. Commenting on the parallel text in Matthew 15:7, where the Pharisees are also called hypocrites, McCarren (2013:60) says: 'Dressing up sin as virtue is a shameless hoax, mere pious playacting'.

\section{Mark 7:14-23}

As we saw, Mark 7:14-23 is used by certain NPPC leaders to justify feeding people strange and even dangerous substances. The first observation important to the current

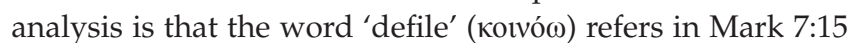
to ancient Jewish notions of religious purity (cf. 1 Macc 1:47, 62, Ac 10:14-15, 28; 11:8-9; 21:28, Rm 14:14, Heb 9:13; 10:29, $\operatorname{Rv} 21: 27)$. This is confirmed by the literary context, because the words of Jesus are framed by the Pharisees' challenge in the preceding passage (Mk 7:1-13) that the disciples of Jesus eat with unclean hands (cf. France 2002:277; Nolland 2005:611).

Purity regulations were important to ancient Jews and regulated most if not all aspects of ancient Jewish life, including what one could wear, who one could interact with and what one could eat. As Malina (1993) explains:

$[P]$ urity rules deal with system and order, with definitions of general boundaries and of exclusivity. [They] present a sort of grid that covers all aspects of society. [They] have a place for everything and everyone, with everything and everyone in its place - and with anomalies properly excluded. (p. 157)

Referring to purity laws in particular, Garland (1996:279-280) writes: 'The laws created the illusion of an ordered cosmos, with carefully erected boundaries that kept every person and thing in its proper place'. In ancient Judaism, food was categorised according to degrees of purity. The rationale for these categories of purity was based in large part on the order of God's perfect creation, including his creation of animals (see Keil \& Delitzsch 1996:558; Neyrey 1996:88-89).

Leviticus 11 lists these dietary categories and explains which types of food are pure and which are not (Neyrey 1996:80; Pilch 1998:171; see Malina 1993:163-165). Jews were not allowed to eat impure or unclean types of food. If they did, they became impure themselves (Neyrey 1996:80). Regarding land animals, they could eat 'any animal that has a divided hoof and that chews the cud' (Lv 11:3, NIV). If the land animal had none or only one of these two characteristics, ancient Jews were not allowed to eat them (Keil \& Delitzsch 1996:559). This regulation made camels, hyraxes, rabbits and pigs unclean, among others. Similar regulations applied to sea animals and animals of the air. Regarding the former, Leviticus 11:9 states: 'Of all the creatures living in the water of the seas and the streams you may eat any that have fins and scales' (NIV). In other words, Jews were not permitted to eat any sea creatures without fins and scales. Verses 13-19 go on to list the birds and flying animals that are unclean, and verses 20-23 explain the rules for flying insects. Malina (1993:163) explains the logic behind these categories. Animals are categorised according to their different habitats, with the three overarching habitats being water, air and land. Animals that fall outside or between these categories are instantly rejected as anomalies and abominations. Amphibians represent a good example, living between and within two separate habitats (Lv 11:10). Also anomalous are any animals that have the defining characteristics of members of a different category, like insects that have wings but move around like land animals by going on all fours ( $\operatorname{lv} 11: 20)$, or land animals that copy fish or insects by swarming around (Lv 11:29-38). Finally, animals that lack some of their key identifying features for that particular category are also considered abominations, like eels and crabs, which live in water but do not have scales or fins.

More directly relevant to our focus is Leviticus 11:29-30:

Of the animals that move along the ground, these are unclean for you: the weasel, the rat, any kind of great lizard, the gecko, the monitor lizard, the wall lizard, the skink and the chameleon. (NIV)

Here, rats are explicitly mentioned as being unclean. Another text directly relevant to our focus is Leviticus 11:41-42:

Every creature that moves along the ground is to be regarded as unclean; it is not to be eaten. You are not to eat any creature that moves along the ground, whether it moves on its belly or walks on all fours or on many feet; it is unclean. (NIV)

The phrase 'creature that moves along the ground' refers to crawling insects and creatures, which would presumably include ants. The phrase 'moves on its belly' refers undoubtedly to worms and snakes (Keil \& Delitzsch 1996:567). In other words, traditional Jewish law forbade eating rats, ants and snakes.

Let us now turn to the text at hand. Jesus essentially negates and nullifies these traditional purity regulations in Mark 7:14-23 (Boring 2006:201; see Pilch 1998:171-172). In fact, the passage expressly says as much in verse 19: 'In saying this, Jesus declared all foods clean' (Bock 2015:224; Boring 2006:203). According to Neyrey (1996:80), 'Jesus himself shocked the Pharisees when he "declared all foods clean"' (Mk 7:19). This would not only have been true for the Pharisees, but for all ancient Jews because the differentiation between clean and unclean food was universal in ancient Judaism (Carter 2001:319). The food laws in Leviticus 11 and 17 , together with the notion of ritual purity as such, were central to Jewish identity and culture, serving not only to distinguish and earmark this group as the chosen people of God, but also to separate them from others, which are two sides of the same coin (Boring 2006:203; France 2002:277).

It is no wonder that this issue was so central to disputes in early Christianity, often threatening to divide early 
Christian communities (cf. Ac 10:9-16; 15:1-29, Gl 2:11-14, 1 Cor 8-10, Rm 14:1-15:13, Col 2:20-23). According to Perrin (1967:150), the statement by Jesus that nothing from the outside can defile a person is 'perhaps the most radical statement in the whole of the Jesus tradition'. As verse 19 points out, this statement meant that Jesus declared all foods to be clean (Boring 2006:203). If all foods are clean, then the traditional purity regulations applicable to food are cancelled. Jesus argues against traditional Jewish law that food cannot ritually defile a person and make him/ her impure. Instead, the actions that result from evil thoughts and an evil heart defile a person (Bock 2015:220, 224; cf. McCarren 2013:61). In the words of Donahue and Harrington (2002:226), Jesus argued that 'true defilement is rooted in inner distortion rather than in external observance'. France (2002:292) agrees: "'Defilement", then, is seen exclusively in moral terms' (cf. also Bock 2015:225; Pilch 1998:171-172).

Because rats and snakes, among other animals, should be considered edible food, the passage may be regarded as allowing the consumption of these animals. In fact, one of the aims of this passage is to speak against the classification of food into clean and unclean. In this regard, modern distinctions between acceptable and unacceptable food is also questioned. People eat different types of food in different countries across the world. As long as animals are treated humanely and endangered species are not eaten illegally, no one has the right to criticise what other individuals and/or cultures choose to eat. It has to be stated, though, that the caveats of treating animals humanely and not eating endangered species are not derived from Mark 7:14-23, but from contemporary considerations and categories. Be that as it may, the point here is that Mark 7:14-23 could be taken to allow the consumption of rats and snakes, irrespective of how distasteful some people may find it. This is supported by Leviticus 11 considered above. If traditional Jewish law expressly forbade the consumption of ants, rats and snakes, and Jesus subsequently declared all of these regulations across the board as null and void, then the inescapable conclusion must be that Jesus allowed the consumption of these animals.

The passage does not, however, say anything about the preparation of such food. Although there were traditional Jewish laws about the preparation of food (e.g., Lv 17:10 14, Dt 12:23-27), Mark 7:14-23 does not address or respond to these regulations. The passage may therefore not be used as a proof-text to justify the consumption of live animals. Much of the public outcry against the actions of the NPPCs mentioned above is against the eating of animals while they are still alive. For example, Prophet Penuel Mnguni of End Times Disciples Ministries was arrested and charged by the South African Police Service for coercing people to eat rats and ants, but the charges were dropped when it could not be proved that the animals were alive when fed to the congregants (Qiki 2020:39). ${ }^{5}$ One has to assume that the response from the public would generally have been much less boisterous and vociferous if these leaders had cooked the meat and then shared it with their congregants during a common meal. Because the topic of food preparation is not addressed in this passage, one has to accept that usual procedures are assumed, like the cooking of animal meat. Because the text says nothing about eating live animals, it cannot be used to justify such practices. One has to acknowledge that the text also fails to prohibit the eating of live animals and can therefore not be used as a proof-text to disallow the eating of live animals. Nonetheless, it is the NPPC leaders who use this text as a proof-text, not their critics. Ultimately, Mark 7:14-23 does not address the question of whether or not people should be allowed to eat live animals. Although the statement 'nothing that enters a person from the outside can defile them' might seem generic enough to allow the consumption of anything, it refers in this context narrowly and exclusively to the classification of animals into clean and unclean (Berkley 2001:n.p.). The question of whether or not one should be allowed to eat live animals is a moral question about respect for all living creatures, which is not addressed by this text, apart from the general proposal by Jesus that moral purity is more important than cultic purity (cf. Bock 2015:225).

It is important to note that in Mark 7:14-23 Jesus addresses the topic of edible food, not harmful substances (Berkley 2001:n.p.). The passage does not address the consumption of anything considered harmful, but the traditional Jewish restrictions concerning edible food. Just like the passage cannot be taken to validate the use of alcohol, tobacco or recreational drugs (Berkley 2001:n.p.), it does not permit or justify the consumption of harmful substances like petrol or Dettol. Although the text says that nothing entering the body can defile a person, it does not say that nothing entering the body can kill or harm a person. The issue being addressed here by Jesus is that of dietary purity regulations, not that of poisonous or toxic substances.

As we have seen, one of the criticisms against the NPPC leaders discussed earlier is that they coerce or force people to consume certain substances. Although Mark 7:14-23 does not address this concern directly, it does do so indirectly. In this text, Jesus speaks out against the tendency of ancient Judaism and Jewish leaders to regulate what people may or may not eat, and to compel people to only eat certain types of food. Any attempt by religious leadership to compel or control what people eat is therefore challenged by this text. One has to presume that the same would apply to the actions of certain NPPC leaders today, especially if such substances are harmful to humans. In his public ministry, Jesus is only ever seen doing miracles for the benefit of humans, not to harm them. In fact, the Markan (and canonical) Jesus is typically portrayed as transgressing purity regulations and established traditions for the express purpose of healing and

5.A YouTube video of the eNCA news report is available at https://www.youtube.com/ watch?v=NBf7knVgOuE. As the news reporter points out, the rat seems to have a heartbeat on a recording of the incident. 
improving the lives of the poor and marginalised, often to the annoyance of religious leaders (Iverson 2011:200).

In fact, the shift in emphasis from purity regulations to a person's inner being that Jesus advocates in Mark 7:14-23 was at least in part intended to improve interpersonal relations and prevent causing harm to others. The repeated use of the word 'heart' ( $\kappa \rho \rho \delta i \alpha)$ in Mark 7:14-23 is important in this context. For ancient Jews and Christians, the heart was the core of a person's inner being, similar to but not exactly the same as modern notions of the soul (cf. Donahue \& Harrington 2002:224; Luz 2001:334; Senior 1998:179). More importantly, the heart was the locus of a person's emotions and thoughts, and the driving force of a person's actions, including morally good and bad emotions and actions (Boring 2006:203; Carter 2001:317, 320; Schnackenburg 2002:149; Wessel 1984:680). Donahue and Harrington (2002:224) describe the heart as 'the battleground between good and evil'. Jesus argues that when it comes to purity, the focus should be on someone's heart, and because food does not enter a person's heart, it cannot defile that person. France (2002:292) states it as follows: 'Unlike the things which do not

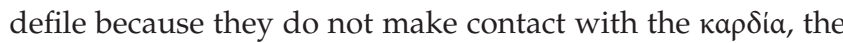
really defiling things are those which actually originate in the

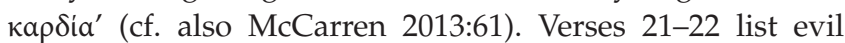
thoughts that come 'from within, out of a person's heart' and lead to evil actions, namely 'sexual immorality, theft, murder, adultery, greed, malice, deceit, lewdness, envy, slander, arrogance and folly' (Stein 2008:14). These are all thoughts and actions of humans that harm other people (Bock 2015:225; Garland 1996:276). Boring (2006:205) calls them 'sins against other people, actions that damage relationships and community'. Malina (1993) writes:

Thus, in the interpretation of the parable on clean and unclean (Mark 7:14-23), 'what comes out of a person is what defiles a person'. And note that the evil intentions generated by the heart refer to interpersonal relationships that do harm to one's fellows. (p. 174)

Mark's list of vices is unique when compared with similar Jewish and Hellenistic lists in that it emphasises sins against one's fellow human beings instead of sins against Israel or God (Donahue \& Harrington 2002:225).

Applying the current text to a modern context, Garland (1996:277) writes: 'Traditions become evil when they run counter to God's purposes expressed in the ethical commands of how to relate to others'. The same can be said not only of church traditions, but also of any church practices and rituals. If the actions of certain NPPC leaders are motivated by intentions like greed, deceit and arrogance, as many of their critics claim, then these actions are harmful to others and condemned by Jesus. These sins are explicitly mentioned in Mark 7:21-22. Moreover, the sexual exploitation of people, especially women, by some of these leaders is likewise condemned in this text when it explicitly refers to sexual immorality and lewdness as evil. Finally, if substances like Dettol and petrol could result in serious injury or death, the explicit mentioning of murder in this list of transgressions is relevant. If someone were to die from consuming a harmful substance at the behest of an NPPC leader, would that not be murder? At the very least, it would qualify as culpable homicide. In Mark 7:14-23, Jesus calls for a shift in emphasis from purity regulations, enforced by the religious leaders of the time, to people's intentions and treatment of one another (cf. Donahue \& Harrington 2002:226; Malina 1993:174). Bock (2015) writes:

Washed hands are nothing compared to these acts [in Mark 7:21-22] that we are responsible for doing and that do damage to others. Defilement is not only about what we do but also about how that impacts others. (p. 225)

This emphasis should not necessarily be seen as a deviation from traditional Jewish law because Leviticus itself, after discussing the laws about ritual purity in chapters 1-18, continues in chapter 19 to not only promote fairness and charity in one's social interactions with others, but to also condemn the types of damaging social interactions with others listed in Mark 7:21-22 (Donahue \& Harrington 2002: 228-230). Jesus' aim with this list of vices was to promote a better society, where people's main focus is on how they treat their fellow human beings instead of how well they implemented purity regulations. By extension, Mark 7:21-22 could be applied to the context of contemporary Christianity to condemn any practices that fail to improve society and promote the humane treatment of other people (and animals), especially by religious leaders (Garland 1996:277).

To summarise, although Mark 7:14-23 supports the eating of animals like ants, rats and snakes, it cannot be used as a proof-text to justify the eating of live animals. Furthermore, the text condemns forcing people to eat or not eat certain types of food, especially when this is done by religious leaders. Most importantly, the text speaks against doing anything to harm others, including feeding them harmful substances and exploiting them sexually.

\section{Matthew 15:1-20}

The Matthean version of this pericope is not much different from the Markan one. There are, however, some minor changes that have led some scholars to argue that Matthew either downplays the cancellation of purity distinctions between clean and unclean food, or fails to portray Jesus as cancelling these distinctions at all (e.g., Davies 1993:111-113; Keener 1999:410; Senior 1998:177). Such editorial activity would make sense for Matthew, considering his portrayal of Jesus in Matthew 5:17-20 (cf. Carter 2001:320; Davies and Allison 2004:517, 537; Evans 2012:300). If Matthew 15:1-20 promotes the cancellation of purity regulations about food, it would seemingly contradict Matthew 5:17-20 (Luz 2001:332; cf. Evans 2012:301; see also Mt 8:1-4; 23:23-26). In the latter,

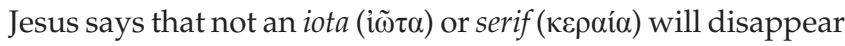
from the Mosaic Law before the apocalyptic or eschatological end. He continues to say that if anyone loosens, weakens, annuls or repeals - these are all meaning possibilities of $\lambda v \omega$ -'one of the least of these commands and teaches others accordingly', that person 'will be called least in the kingdom 
of heaven' (NIV). It follows that if Jesus annuls purity regulations about food in Matthew 15:1-20, the phrase 'least in the kingdom of heaven' would apply to him as well. Surely, this could not have been Matthew's intention. Matthew 5:17-20 concludes in verse 20 with Jesus saying that 'unless your righteousness surpasses that of the Pharisees and the teachers of the law, you will certainly not enter the kingdom of heaven' (NIV). Does this mean that even the nonscriptural Pharisaic tradition about washing one's hands before eating must be expected from the followers of Jesus? This is highly unlikely, because Matthew 5:17-20 is about following recorded Mosaic law and not subsequent Jewish traditions. However, it does apply to purity distinctions between clean and unclean food. Not only are the followers of Jesus to follow Old Testament purity regulations, including those about food, but they must be more stringent and rigorous than even the Pharisees when it comes to following these commandments. It is difficult to square this with the tradition in Mark 7:14-23 that Jesus abolished purity distinctions between clean and unclean food, which would explain why Matthew might have wanted to soften or remove the abolishment of purity regulations about food in Mark 7:14-23 during his editorial activity.

Let us now consider whether Matthew did indeed downplay or eliminate this radical aspect of the Markan text. The first editorial change by Matthew relevant to the current discussion is his omission of the authorial comment in Mark $7: 19 \mathrm{~b}$ that Jesus declared all foods to be clean (Evans 2012:300). One could argue that by removing this authorial comment, Matthew essentially introduces ambiguity into the story about whether Jesus did indeed nullify purity distinctions between clean and unclean types of food (cf. e.g., Keener 1999:413-414). The second editorial change relevant here is Matthew's addition of the comment that eating with unclean hands does not defile a person at the conclusion of the Matthean pericope in verse 20. According to France (2002), this edit:

$[B]$ rings the discussion safely back at the end to the less controversial issue of hand washing, a matter of scribal tradition, not of OT [Old Testament] law, thus keeping Jesus clear of the charge of doing precisely what he had claimed in Mt. 5:17 not to be doing, 'abolishing the law'. (p. 279)

The third editorial change relevant here is that Matthew changed the order in which the material is presented by swapping around the discussion of honouring one's parents and the quotation from Isaiah (Bock 2015:222). According to Senior (1998:177), this modification 'puts the focus of the debate on the tenor of the Pharisees' teaching rather than the validity of the cultic practice'. The fourth editorial change relevant here is Matthew's choice in verse 11 to adapt the saying of Jesus in Mark 7:15 that 'nothing entering a person from the outside can defile them' in a way that

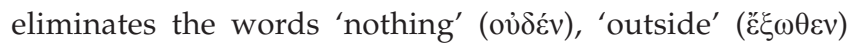

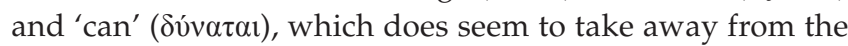
rhetorical force, radicality and specificity of Mark's version (Dunn 1990:41, 51).
There are, however, other explanations for these redactional changes. Firstly, Matthew might simply have removed the authorial comment in Mark 7:19b because his Jewish audience would have understood the implication of Jesus' statement that whatever enters the mouth does not defile someone (cf. Duling 2010:298, 302). Although Mark needed to explain the implications of this pronouncement to his Gentile audience, Matthew did not (Davies \& Allison 2004:516). In this regard, France (2002) rightly says:

$[I] \mathrm{t}$ is surely incredible that an evangelist (of Matthew's acute sensitivity to matters of Jewish law) who retained the crucial epigram of 15:11 could have been unaware, or expected his Jewish readers to be unaware, of its implications for the food laws. (p. 279)

Secondly, Matthew could have added the comment that eating with unclean hands does not defile a person at the end of his narrative to form an inclusio between Matthew 15:1-2 and Matthew 15:20, thereby marking the whole passage in Matthew 15:1-20 as a single pericope (Luz 2001:325, 334). Thirdly, swapping around the discussion about honouring one's parents and the quotation from Isaiah could merely have been motivated by an attempt to smooth out Mark's ineloquent structure by improving the logical progression of ideas (Schnackenburg 2002:147). According to Luz (2001:326), the net result of swapping around these two traditions is that Matthew 'creates in vv. 4-9 a thematically unified, clearly structured, and, in comparison to Mark, sharpened controversy'. Matthew's version also presents the Law and the Prophets in the correct order (Davies \& Allison 2004:518).

Finally, the choice to remove the words 'nothing' (oủ $\delta \varepsilon v)$,

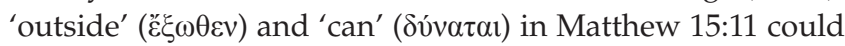
be merely a stylistic choice, toning down the crudeness of Mark's version. Even with this modification of Mark 7:15 in Matthew 15:11, the semantic meaning of the statement remains the same, as does its elucidation in Matthew 15:1620 (par. Mk 7:18-23). Both the semantic meaning and the subsequent elucidation of Matthew 15:11 lead to the conclusion that Jesus declared all foods clean. What is more, Matthew's editorial changes actually clarify the meaning of the saying (Davies and Allison 2004:527). These modifications include changing some of the vocabulary (as we have seen), enhancing the parallelism between the two clauses, improving the grammar and, most importantly, adding 'the mouth' to both clauses to make it clear that the saying applies to purity regulations about food in particular (see Nolland 2005:619-620). The cumulative result of these editorial changes is best articulated by Davies and Allison (2004:527) as 'a shorter, less cryptic, more explicit statement'. From this point of view, Matthew has in fact increased the radicality, specificity and rhetorical force of the saying. One has to agree with France (2002) in this case:

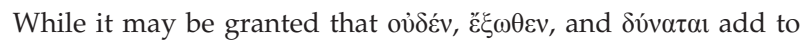
the rhetorical force of the pronouncement, it is not clear that the Matthean form is any more 'ambiguous': the principle that defilement comes from inside and not from outside is equally 
clear, and indeed Matthew's specific mention of what goes into and comes out of the mouth might rather be said to make the application to the food laws even more 'inevitable'. Mark has certainly made a more explicit comment on the implications of Jesus' $\pi \alpha \rho \alpha \beta$ $\lambda \eta \dot{~ i n ~ v . ~ 19, ~ b u t ~ i n ~ t h e ~ b a s i c ~ s a y i n g ~ i t s e l f ~ n e i t h e r ~}$ evangelist leaves any room for ambiguity. (p. 290)

Ultimately, the pronouncement by Jesus that whatever enters the mouth does not defile someone is determinative in this context and leaves no doubt that Jesus is also in Matthew portrayed as nullifying purity regulations regarding clean and unclean food. Again, one has to agree with the finding of France (2002) in this regard:

It is permissible to find in Matthew a more apologetically careful record of Jesus' views on purity, but to regard his version as totally innocuous from the point of view of the continued validity of the food laws is naive. (p. 279)

Even if one accepts that Matthew's editorial activity downplays the radical nature of Jesus' pronouncement that all types of food are clean, it would still not eradicate the statements in verses 11 and 17-18 that whatever enters the mouth does not defile someone, together with the necessary and inevitable implication of this statement that all foods are clean. Luz (2001:332) is therefore correct when he says the following about verse 11 in particular: 'With Matthew the difficulty is that while he has reworked the Markan text, he did not do so enough that an interpretation different from Mark's would convincingly result'. In this context, one does well to recall Perrin's (1967:150) comment, quoted above (see p. 5), that Matthew 15:11 (like Mk 7:15) is 'perhaps the most radical statement in the whole of the Jesus tradition'.

There is another consideration important to the current discussion. Davies and Allison (2004:517, 527-531) argue that it is possible to understand Matthew 15:11 not as a nullification of purity laws, but as an overstated rhetorical appeal to shift one's focus from physical purity to moral purity. In other words, they argue that verse 11 should be understood 'in a relative, not absolute sense: what counts above all is the heart' (Davies \& Allison 2004:531; see Nolland 2005:608, 620-621). The problem with this suggestion is that it proposes a reading that is not commensurate with the literal meaning of the text, which explicitly says that what goes into the mouth does 'not' (oủ) defile a person. In fact, the word 'not' (oủ) is emphasised by the Greek syntax, which features the negative particle first in the logion. Luz (2001:332) is therefore correct: 'To be sure, it [verse 11] can hardly be interpreted linguistically as a so-called dialectic negation ("Not so much what goes into a person as...")'. The suggestion by Davies and Allison also ignores the biological explanation in verses 17-18, where the heart replaces the stomach as the locus of purity. This goes against the claim by Davies and Allison (2004: 531) that ' $[t]$ he immediate literary context does nothing to encourage an interpretation in terms of OT food laws'. A stronger case can perhaps be made for verses 17-18 toning down the radicality of Jesus' claim than for verse 11 (France 2002:290), but the contrast between stomach and heart still leads to the same inevitable conclusion, although more hidden here than in Mark, that food does not defile.

Despite his claim that Matthew does not edit the Markan source sufficiently to remove the nullification of purity regulations regarding food, Luz (2001) still maintains that Matthew:

$[D]$ id not want to eliminate the purity commandment fundamentally but understood our Jesus saying [verse 11] as a pointed formulation that aims at the priority of the love commandment over the purity regulations. (p. 333)

He reaches this conclusion based on his examination of Matthew's view of purity laws in the rest of the Gospel. To distinguish between what Matthew said and what he wanted to say is, however, untenable. An exegete can only work with the text in front of her or him. It is impossible to know the internal thoughts or intentions of Matthew. Whatever they might have been, Matthew did not edit away Mark's nullification of purity regulations regarding food, but at most softened Mark's rhetoric, as Luz himself admits (see above).

If one accepts that Matthew 15:1-20 portrays Jesus as nullifying purity regulations about clean and unclean food, what does that mean for the relationship between Matthew 15:1-20 and Matthew 5:17-20? There seems to be two options available for understanding the relationship between these two texts. The first is to accept that the two texts contradict each other. This conclusion would be legitimate if one accepts that there are other contradictions within and between the canonical Gospels as well. Matthew's decision to retain the contradiction could then be explained as a penchant to stay true to both of his principal sources when writing his Gospel, with Matthew 5:18 deriving from Q 16:17, and Matthew 15:1-20 deriving from Mark 7:1-23 (see Howes 2018:160-161). If this is true, it would mean that Matthew decided to preserve both of these traditions in his Gospel despite the contradiction.

The other option is to consider the moral purity that Matthew 15:1-20 advocates as the true fulfilment of Mosaic law so that the replacement of physical purity laws (about food, in this case) with ethical purity laws (that defile the heart) represents not the abolition or nullification of established Jewish law, but the fulfilment of its true intention from the start (cf. Boring 2006:203-205; Luz 2001:334; Senior 1998:179). Such an interpretation does indeed iron out the apparent contradiction between the two Matthean texts (cf. Sigal 2007:24-25), but not everyone would accept the legitimacy of this interpretation. What about the comment in Matthew 5:20 that the followers of Jesus must surpass the Pharisees in righteousness? The question here is whether the word

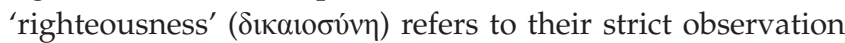
of Jewish law or their righteousness more generally. The lexical meaning of this word includes both 'fulfilment of the Law' and 'righteousness' in general (Liddell \& Scott 1996:429; cf. LXX Is $26: 2$ for the former). Given that the discussion in 
Matthew 5:17-20 is about Mosaic law, the former meaning is perhaps more likely. At any rate, a detailed study of the relationship between these two Matthean texts - in addition to other texts like Matthew 8:1-4 and 23:23-26 - would be necessary to reach a final conclusion about which option is preferable, and such an investigation lies beyond the scope of the current study.

If we are correct that the Matthean Jesus also nullifies purity regulations regarding clean and unclean food, everything said in the previous section on the relevance of Mark 7:1-23 for the strange practices of certain NPPCs applies here as well. Although Matthew 15:1-20 (like Mk 7:1-23) does allow the consumption of all animals, it cannot be used as a proof-text to justify the consumption of live animals or harmful substances, which is not at issue here. More importantly, both the Markan and the Matthean versions of this pericope warn against actions that harm others. It is true that Matthew, influenced by the 10 commandments in the Old Testament, reduces the number of vices listed in Mark 7:21-22 from 12 to 6, or from 13 to 7 if you include 'evil thoughts' in the list (Bock 2015:225). Even so, Matthew still includes sins like murder, sexual immorality and false testimony, all of which potentially apply to the NPPC leaders. In any case, this list is not supposed to be exhaustive but represents the types of actions that typically bring harm to other people (cf. France 2002:292).

The addition of 'the mouth' in Matthew's text makes it relevant to the context of NPPCs in another way. According to Luz (2001:333), specifying the mouth has a polemical function to further indict the Pharisees: 'What defiles them is the teaching that comes from their mouth' (cf. Mt 12:33-37; cf. also Evans 2012:301-302). Certain NPPC leaders might say that what goes into the mouth does not defile, but, according to the Matthean Jesus, what comes out of the mouth can indeed defile. This is particularly true of false teachings that originate from an evil heart. Many people would say that this applies to the NPPC leaders mentioned in the introduction to this study (cf. Kgatle 2020c). For example, the Gauteng MEC 6 of Infrastructure Development, Nandi Mayathula-Khoza, responded to the activities of Pastor Lesego Daniel of Rabboni Centre Ministries in Ga-Rankuwa by saying: 'If you go about feeding people grass and petrol, you must know that you are not a good shepherd. You are misleading the flock'. ${ }^{7}$ Father Russell Pollitt, Director of the Jesuit Institute, points out that many of these NPPC leaders lack theological training, which he claims to be dangerous, 'as it often leads to a literal fundamentalist interpretation of texts, the rejection of critical thinking (you must leave your brain at the door) and crazy actions - like snacking on snakes' ${ }^{8}$

Another editorial choice by Matthew is important in the current discussion, relating to Jesus' criticism of the

$$
\text { 6.Member of the Executive Council. }
$$

7.Quotation from an article in the Pretoria Rekord: https://rekordeast.co.za/308968/ mec-warns-of-harmful-religious-practices.

8.Quotation from an article in the Daily Maverick: https://www.dailymaverick.co.za/ article/2015-08-14-religion-we-dont-need-no-regulation/.
Pharisees rather than the nullification of food laws. The most obvious Matthean insertion is at verses 12-14, where Jesus responds to the offense that his words have caused the Pharisees. In verse 13, Jesus implies that the Pharisees are not acting in accordance with the will of God, and that God will reject and expose them in due course (cf. Evans 2012: 301; McCarren 2013:61). In verse 14, Jesus calls the Pharisees blind guides who lead people astray, with disastrous consequences (McCarren 2013:61; cf. Duling 2010:303; Weren 2014:256). According to Luz (2001:333), verses 12-14 intensify the polemic introduced by the addition of 'the mouth' in verse 11 . To the extent that the actions of certain NPPC leaders cause harm to others, the consequences of their leadership are no less disastrous than those of the Matthean Pharisees. In fact, the consequences of their actions are arguably much worse than those of the Pharisees as they are portrayed in the New Testament. Although the Pharisees might have been guilty of being zealous and legalistic, certain NPPC leaders are guilty of putting people's health and lives at risk, including in some cases their sexual well-being.

To summarise, one may reach the same conclusions about the practices of NPPC leaders from Matthew 15:1-20 as from Mark 7:1-23. This is true despite the editorial activities of the First Evangelist. In fact, Matthew's version strengthens at least the potential criticism against certain NPPC leaders. To the extent that these NPPC leaders are comparable to the Pharisees of the New Testament, they similarly act against the will of God and are therefore blind guides who lead people astray, with disastrous consequences. In Matthew, Jesus prophesies that God will reject and expose the Pharisees in due course (Evans 2012:301). To what extent is this also true of those NPPC leaders who prey on the vulnerable and deliberately put people in harm's way?

\section{Conclusion}

When reading Mark 7:1-23 and Matthew 15:1-20 in their literary and socio-cultural contexts, the conclusion is inescapable that these texts condemn rather than condone the questionable and potentially harmful activities of certain NPPC leaders, like spraying insecticides on people's faces, coercing people to consume petrol, Dettol, grass, live rats, ants and snakes, fondling people's private parts and ordering congregants to take off their clothes.

\section{Acknowledgements Competing interests}

The authors declare that they have no financial or personal relationships that may have inappropriately influenced them in writing this article.

\section{Authors' contributions}

V.Q. completed the original research under the supervision and guidance of L.H. L.H. reviewed, edited and drafted the final submission to Verbum et Ecclesia. 


\section{Ethical considerations}

This article followed all ethical standards for research without direct contact with human or animal subjects.

\section{Funding information}

V.Q. was the recipient of UJ's supervisor-linked bursary for his MA degree. No other grants or funding was received for this research.

\section{Data availability}

Data sharing is not applicable to this article as no new data were created or analysed in this study.

\section{Disclaimer}

The views and opinions expressed in this article are those of the authors and do not necessarily reflect the official policy or position of any affiliated agency of the authors.

\section{References}

Berkley, W.E., 2001, The expository files: What man-made rules cannot do, viewed 03 October 2020, from https://www.bible.ca/ef/expository-mark-7-14-23.htm.

Bock, D., 2015, Mark, Cambridge University Press [New Cambridge Bible Commentary], Cambridge.

Boomershine, T.E., 2011, 'Audience address and purpose in the performance of Mark', in K.R. Iverson \& C.W. Skinner (eds.), Mark as story: Retrospect and prospect, pp. 115-142, Society of Biblical Literature, Atlanta, GA.

Boring, M.E., 2006, Mark: A commentary, Westminster John Knox [New Testament Library], Louisville, KY.

Bratcher, R.G. \& Nida, E.A., 1961, A translator's handbook on the Gospel of Mark, Brill, Leiden.

Carter, W., 2001, Matthew and the margins: A sociopolitical and religious reading, Orbis Books [The Bible and Liberation Series], New York, NY.

Davies, M., 1993, Matthew, Journal for the Study of the Old Testament Press, Sheffield.

Davies, W.D. \& Allison, D.C., [1991] 2004, A critical and exegetical commentary on the Gospel according to Saint Matthew, Volume II: Commentary on Matthew VIIIXVIII, T\&T Clark [ICC], London.

Donahue, J.R. \& Harrington, D.J., 2002, The Gospel of Mark, The Liturgical Press, Collegeville, PA.

Duling, D.C., 2010, 'The Gospel of Matthew', in D.E. Aune (ed.), The Blackwell companion to the New Testament, pp. 296-318, Wiley-Blackwell, Malden, MA.

Dunn, J.D.G., 1990, Jesus, Paul, and the law: Studies in Mark and Galatians, Westminster John Knox Press, Louisville, KY.

Evans, C.A., 2012, Matthew, Cambridge University Press [New Cambridge Bible Commentary], Cambridge.

France, R.T., 2002, The Gospel of Mark: A commentary on the Greek text, William B. Eerdmans, Grand Rapids, MI.

Garland, D.E., 1996, Mark, Zondervan, Grand Rapids, MI.

Gould, E.P., 1969, A critical and exegetical commentary on the Gospel according to St Mark, T\&T Clark [International Critical Commentary], Edinburgh.

Harrington, D.J., 1991, The Gospel of Matthew, The Liturgical Press [Sacra Pagina Series], Collegeville, PA

Howes, L., 2018, “'You will not get out of there!": Reconsidering the placement of Q 12:58-59', Neotestamentica 52(1), 141-178. https://doi.org/10.1353/ neo.2018.0004
Iverson, K.R., 2011, "Wherever the gospel is preached": The paradox of secrecy in the Gospel of Mark', in K.R. Iverson \& C.W. Skinner (eds.), Mark as story: Retrospect and prospect, pp. 181-209, SBL, Atlanta, GA.

Jentile, T., 2016, 'The moral formation, pastoral leadership and contemporary Pentecostal/Charismatic churches in Soweto', Master's thesis, University of the Free State, Bloemfontein

Keener, C.S., 1999, A commentary on the Gospel of Matthew, William B. Eerdmans, Grand Rapids, Ml.

Keil, C.F. \& Delitzsch, F., 1996, Commentary on the Old Testament, Volume 1 Hendrickson, Peabody, MA.

Kgatle, M.S., 2017, 'The unusual practices within some neo-Pentecostal churches in South Africa: Reflections and recommendations', HTS Theological Studies 73(3), 1-8. https://doi.org/10.4102/hts.v73i3.4656

Kgatle, M.S., 2020a, 'New paradigms of pneumatological ecclesiology brought about by new prophetic churches within South African Pentecostalism', Verbum et Ecclesia 41(1), 1-6. https://doi.org/10.4102/ve.v41i1.2053

Kgatle, M.S., 2020b, 'Towards a balancing act between the emergence of prophetic churches and organisational culture in South African Pentecostalism', Verbum et Ecclesia 41(1), 1-7. https://doi.org/10.4102/ve.v41i1.2118

Kgatle, M.S., 2020c, 'Propagating the fear of witchcraft: Pentecostal prophecies in the new prophetic churches in South Africa', Journal of the European Pentecostal Theological Association 40(2), 1-12. https://doi.org/10.1080/18124461.2020.1795420

Khanyile, S.B., 2016, 'The virtualization of the church: New media representations of Neo-Pentecostal performance(s) in South Africa', Master's dissertation, University of the Witwatersrand, Johannesburg.

Liddell, H.G. \& Scott, R., 1996, A Greek-English Lexicon, 9th edn., rev. edn. and augmented $\mathrm{H}$. S. Jones and R. McKenzie, Clarendon, Oxford.

Luz, U., 2001, Matthew 8-20: A commentary, Fortress Press [Hermeneia] Minneapolis, MN.

Malina, B.J., 1993, The New Testament world: Insights from cultural anthropology, rev. edn., Westminster John Knox, Louisville, KY.

Maluleke, TS, 2015, 'Between Pretoria and George Goch Hostel: God in South Africa in 2015', New Agenda: South African Journal of Social and Economic Policy 59, 35-39.

McCarren, P.J., 2013, A simple guide to Matthew, Rowman \& Littlefield, Lanham, MD.

Mokhoathi, J. \& Rembe, N.S., 2017, 'Religious liberties and the constitution of South Africa: A call for religious accountability', Scriptura 116(1), 1-10.

Neyrey, J.H., 1996, 'Clean/unclean, pure/polluted, and holy/profane: The idea and the system of purity', in R.L. Rohrbaugh (ed.), The social sciences and New Testament interpretation, pp. 80-104, Hendrickson, Peabody, MA.

Nolland, J., 2005, The Gospel of Matthew: A commentary on the Greek text, William B. Eerdmans [New International Greek Testament Commentary], Grand Rapids, MI.

Perrin, N., 1967, Rediscovering the teaching of Jesus, Harper \& Row; SCM, New York, NY

Pilch, J.J., 1998, 'Purity', in J.J. Pilch \& B.J. Malina (eds.), Handbook of biblical social values, pp. 170-173, Hendrickson, Peabody, MA.

Qiki, V., 2020, All "doom" and gloom?: The unusual ritual practices of New Prophetic Pentecostal Churches in South Africa in light of the New Testament Gospels', Master's dissertation, University of Johannesburg, Johannesburg.

Resane, K.T., 2017a, "'And they shall make you eat grass like oxen" (Daniel 4:24): Reflections on recent practices in some new charismatic churches', Pharos Journal of Theology 98, 1-7.

Resane, K.T., 2017b, 'Miracles in the Neo-charismatic movement: Historical and theological critique', Verbum et Ecclesia 38(1), 1-8. https://doi.org/10.4102/ve. v38i1.1736

Schnackenburg, R., 2002, The Gospel of Matthew, transl. R.R. Barr, William B. Eerdmans, Grand Rapids, MI.

Senior, D., 1998, Matthew, Abingdon Press [Abingdon New Testament Commentary Series], Nashville, TN.

Sigal, P., 2007, The halakhah of Jesus of Nazareth according to the Gospel of Matthew, SBL, Atlanta, GA.

Stein, R.H., 2008, Mark, Baker Academic [Baker Exegetical Commentary on the New Testament], Grand Rapids, Ml.

Weren, W.J.C., 2014, Studies in Matthew's Gospel: Literary design, intertextuality, and social setting, Brill, Leiden.

Wessel, W.W., 1984, 'Mark', in F.E. Gaebelein (ed.), The expositor's bible commentary: Matthew, Mark, Luke (Volume 8), pp. 601-793, Zondervan Publishing House, Grand Rapids, MI. 